\title{
Disaster Risk Reduction Based on Community through a Contingency Plan for Mount Sinabung
}

\author{
Puji Lestari• \\ Eko Teguh Paripurno• \\ Arif Rianto Budi Nugroho•
}

\begin{abstract}
The eruption of Mount Sinabung in Karo district of North Sumatera has continued on and off since 2010. A contingency plan is needed to reduce the risk of disaster. The purpose of this research is to find a disaster communication model in community-based disaster risk management through Sinabung Eruption Contingency Plan of Karo Regency, North Sumatera Province. This research applies the concept and models of community-based disaster management. The research objectives are to make a disaster risk management model based on the community as a contingency plan for Sinabung. A qualitative method is used by the researchers to finish this paper. This research is held in risk area of Mount Sinabung, Karo, Sumatera Selatan. The object of this research is the ability of government, non-government, and also society as actors of concept and models of community-based disaster management communication. The researchers analyze the program and the competency of the actor concept and the models of community-based disaster management communication. The result of this research is a disaster communication model in communitybased disaster risk management through Sinabung Eruption Contingency Plan.
\end{abstract}

\section{Keywords:}

communication; disaster management; Sinabung contingency plan.

\section{Introduction}

Indonesia has many volcanoes that are still active and could erupt anytime. One of them is Mount Sinabung located in Karo Regency, North Sumatera Province. It is a stratovolcano and has four active craters. Since its latest eruption about 1,200 years ago, a phreatic eruption occurred on August 27, 2010 (Sutawidjaja et al., 2013). This mountain has a high risk of disaster (Lestari et al., 2016). Since 2010, Sinabung's eruptions have killed tens of thousands of people and damaged residences and infrastructure. We thought disaster management for disaster risk reduction was needed. The definition of disaster management, according to Carter (Suri et al., 2015), is an applicative science seeking by observation and analysis calamity to systematically increase actions associated with the prevention, reduction, preparation, emergency response, and recovery.

Evaluation of volcanic activity is still tricky at volcanoes after a long-term dormant period (Iguchi et al., 2011). Research on disaster management to disaster risk reduction is necessary, especially with a potential disaster,

\footnotetext{
- Universitas Pembangunan Nasional Veteran, Yogyakarta. Email: pujilestariupn@gmail.com
} 
like for example the Karo District, North Sumatera eruption phase of Mount Sinabung since it is very vulnerable.

Disaster Management in Indonesia is outlined in Article 1 paragraph (6) of Law No.24 of 2007 (Presiden Republik Indonesia, 2007). It states that the implementation of disaster management is a series of efforts covering the establishment of development policies at risk of disaster, disaster prevention activities, emergency response, and rehabilitation. Article 3 paragraph (1) explains that the principles of disaster management, namely humanity, justice, equality of law and government, balance, harmony, order and legal certainty, togetherness, environmental sustainability, and science and technology. In paragraph (2), the principles of disaster management are quickly and precisely, prioritized.

The objective of disaster management, according to Law No. 24 of 2007 Article 4, is to protect the community from disaster threats. The other objective of disaster management is to harmonize existing legislation, to ensure the implementation of disaster management in a planned, integrated, coordinated and comprehensive manner. Then, respecting local culture, building public and private partnerships and encouraging the spirit of cooperation, solidarity, and generosity and creating peace in the life of the society, nation and state.

The implementation of the Law has been supported by Government Regulation No. 21, on the Implementation of Disaster Management. The essence of disaster management is the coordination before the disaster, during the disaster and after the disaster. The National Disaster Management is expected to coordinate disaster management communication aspects (Presiden Republik Indonesia, 2008).

According to (Asteria, 2016), disaster management is the management of information related to the disaster, message delivery and message reception from the pre-disaster stage, during the disaster and post-disaster. The role of disaster communication determines the success of the government to provide information for public security and to overcome the disaster. This study contributes that the optimization of disaster communication in an integrated manner is important in disaster management. Related to communication, comprehensive disaster management is an effort to prevent and reduce the risk of disaster to manage production process messages or information about the disaster, the messages and message retrieval of the stage post-disaster (Lestari et al., 2013). This study focuses on disaster communication management through coordination implemented in the review of Sinabung Contingency Plans that resulted in the draft of the updated Sinabung Contingency Plan.

One of the most critical pillars of disaster communication management is CommunityBased Disaster Risk Management as a disaster mitigation practice that is institutionalized with more systematic knowledge and concepts. There are some critical elements of community building that are always attached to the understanding of the community. First, the territory or locality (area), or material aspect where a group of individuals lives and fosters their social life. Together with human individuals, this element is critical and a necessary condition for the establishment of a community. The territory becomes the residence of a community. Without a territory, there will never be a community. Second, common ties that make up the social networking constructed by members of the community. In some ways, these social networks help certain individuals to easily find ways of survival (ways to survive). Third, social interaction that is formed among individual members of a community. These three aspects will always appear together to define the characteristics of a community (Nasution, 2005). The community referred to in this study is the region and the people 
who live in Karo Regency around Sinabung. This community conducts activities through coordination and communication to reduce the impact of the eruption of Mount Sinabung.

According to (Sagala et al., 2014), Community-Based Disaster Risk Management is an approach that encourages grassroots communities to manage disaster risks at the local level. Such efforts require a range of efforts that include self-interpreting the disaster threats and risks it faces, prioritizing disaster mitigation, mitigating and monitoring and evaluating its performance in disaster reduction efforts. Community-Based Disaster Risk Management is also a reflection of the belief that communities have the fullest right to determine the types and ways of disaster management in their context. This is an implication of the ownership of fundamental rights to individuals and communities inherent with the right to exercise that right in the form of an opportunity to determine the direction of life itself. Community-Based Disaster Risk Management provides answers that include several principles such as efficiency because ideally, there will be low transaction costs due to the presence of a maximum local intake and a minimum external intake. Community-Based Disaster Risk Management also responds to sustainability issues because the implementation of Community-Based Disaster Risk Management also ensures that effectiveness, legitimacy, and equity are met. Implementation of Community-Based Disaster Risk Management in Indonesia is still looking for form because so far, it tends to be done for the benefit of the actors and donors. On the other hand, the presence of disasters tends to increase, both in intensity, frequency, magnitude, and distribution. Environmental damage is increasing the Sinabung mountain disaster. This can be seen from the disaster that took dozens of lives and thousands of refugees. In this regard, the search for the CommunityBased Disaster Risk Management model for the threat of Mount Sinabung disaster becomes essential to realize the real community toughness.

Various initiatives to build "resilient villages," "alert villages," "harsh villages of disaster," and "mukim daulat disasters community" are still at the forefront of initiatives of various non-governmental organizations and governments and donors. Post-earthquake disaster in Yogyakarta in 2006 and the eruption of Merapi Volcano in 2006 and 2010, Sinabung 2010 and 2013, Community-Based Disaster Risk Management is considered to be one powerful tool to address disaster risk management issues. Many intervention activities are carried out by both government agencies as well as non-governmental organizations, and even the communities are labeled Community-Based Disaster Risk Management. On the other hand, consciously or not, Community-Based Disaster Risk Management becomes ineffective when perpetrators do not have sufficient competence, while disaster risk reduction is needed as in Sinabung, Kabupaten Karo (Figure 1).

\section{Figure 1.}

Roadmap of disaster risk reduction Mount Sinabung

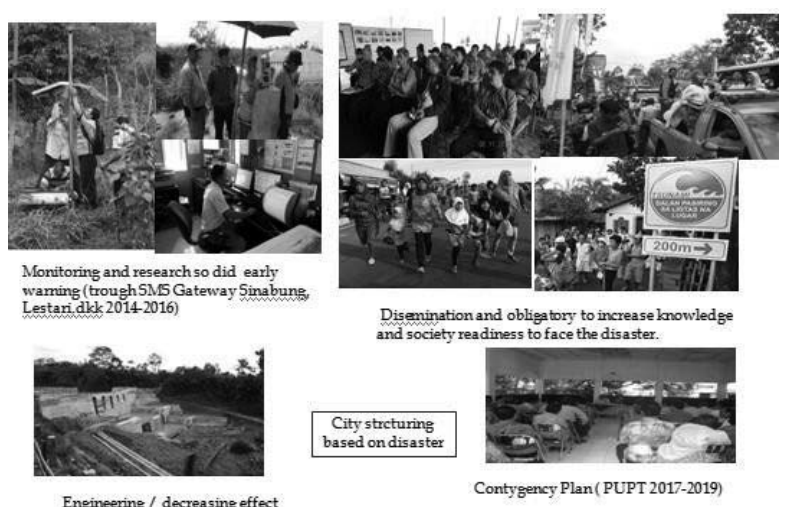

Source: Putra, 2017

This study explores the competence of the perpetrators of Community-Based Disaster Risk Management, with the subject of government agencies, Satuan Kerja Perangkat Daerah (SKPD, Regional Work Unit) and Badan 
Penanggulangan Bencana Daerah (BPBD, Regional Disaster Management Agency) of Karo District, non-governmental institutions, and communities in disaster-prone areas of Mount Sinabung. The purpose of this research is to find a disaster communication model in the community-based disaster risk management through Sinabung Eruption Contingency Plan of Karo Regency, North Sumatera Province.

\section{Methods}

The research was conducted by a qualitative descriptive method. This method is research to create a picture of the problem about the situation or event. Primary data was collected through observation, interview, and focus group discussion (FGD). FGD is a common approach for data collection in qualitative research projects. The primary characteristic of this method is to use interactive data resulting from discussion among participants. The primary strength of the FGD method is that it can provide rich data, more information, and valuable insight that can not be discovered through other methods (Afianti, 2008).

An FGD was held on April 3 and 4, 2017 followed by in-depth interviews. FGD participants are communities related to disaster management, i.e., BPBD, Kesejahteraan Pembangunan dan Perlindungan Masyarakat (Kesbanglinmas, Development and Welfare Community Protection) Service Office in Tanah Karo, the Social Service Office, the Education Office, the Health Office, the Environment Agency. Then, the ministry of communications and information, the Agriculture Office, the Fisheries Office, the Public Works Department, Transportation, Satuan Polisi Pamong Praja (Satpol PP, Public Order Enforcers), Badan Perencanaan Pembangunan Daerah (Bappeda, Regional Development Planning Board), Badan Pengelolaan Keuangan Pendapatan dan Aset Daerah (BPKPAD, Income Financial Management Agency and Local Assets). Also Pusat Vulkanologi dan Mitigasi Bencana
Geologi (PVMBG, Center for Volcanology and Geological Hazard Mitigation) Polisi Resort (Polres, Police Resort), Komando Distrik Militer (Kodim, Military Command District), NGO Representative, Representative of Moderamen, Sekber, MUI, Representative of volunteers, Bank Sumatera Utara, Sub-district of Naman Teran, Tiganderket, and Umbrella. The number of FGD participants and the Renabung Sinabung review workshop included 40 people.

Data collected through FGD includes 1) Experiences ever conducted by participants in various disaster management programs of Mount Sinabung 2013. 2) Constraints experienced during disaster management. 3) Responses on disaster management of Mount Sinabung in 2013. 4) Feedback on disaster management model for the mitigation of the Sinabung disaster. 5) Material and data compilation for the contingency plan for Sinabung disaster mitigation, the locations affected by the disaster, the location of the refugees, the number and characteristics of the affected population, the access of the population to get assistance, the duration of assistance needed and the Information and Public Diplomacy (IDP) profiles the total needs.

A descriptive-qualitative technique analyzed the collected data. First of all, the data is presented in the data displays and then categorized. The next stage is to make interpretations and conclusions of research results. From the drawing of the conclusions, we get an overview of communication models of disaster risk reduction based on the community through a contingency plan.

The community referred to in this matter is the community engaged in making the contingency plan, which consisted of BPBD and Pusat Vulkanologi dan Mitigasi Bencana Geologi (PVMBG, Center for Volcanology and Geological Hazard Mitigation). Also Polisi Resort (Polres, Police Resort), Komando Distrik Militer (Kodim, Military Command District), Head of Satuan Kerja Perangkat Daerah (SKPD, 
Table 1.

Activities and the Role of Actors

\begin{tabular}{|c|c|c|c|c|c|c|c|}
\hline & Activity & Actors & Actors & Actors & Actors & Actors & Actors \\
\hline 1 & $\begin{array}{l}\text { Condition } \\
\text { observation of } \\
\text { volcano }\end{array}$ & PVMBG & & & & & \\
\hline 2 & $\begin{array}{l}\text { Socialization the } \\
\text { condition of volcano }\end{array}$ & PVMBG & Regent & BPBD & & & Radio/TV \\
\hline 3 & $\begin{array}{l}\text { Determination of } \\
\text { status the volcano }\end{array}$ & PVMBG & & & & & \\
\hline 4 & $\begin{array}{l}\text { Socialization the } \\
\text { condition of volcano }\end{array}$ & PVMBG & & & & & \\
\hline 5 & $\begin{array}{l}\text { Coordination status } \\
\text { of the volcano }\end{array}$ & & Regent & BPBD & & & \\
\hline 6 & $\begin{array}{l}\text { Socialization } \\
\text { response of the } \\
\text { volcano }\end{array}$ & & Regent & BPBD & $\begin{array}{l}\text { TNI- } \\
\text { Polri- } \\
\text { SKPD }\end{array}$ & & \\
\hline 7 & $\begin{array}{l}\text { Socialization status of } \\
\text { the volcano }\end{array}$ & & Regent & BPBD & $\begin{array}{l}\text { TNI- } \\
\text { Polri- } \\
\text { SKPD }\end{array}$ & $\begin{array}{l}\text { Community } \\
\text { organization }\end{array}$ & Radio/TV \\
\hline 8 & $\begin{array}{l}\text { Socialization } \\
\text { response of the } \\
\text { volcano }\end{array}$ & & & $\mathrm{BPBD}$ & $\begin{array}{l}\text { TNI- } \\
\text { Polri- } \\
\text { SKPD }\end{array}$ & $\begin{array}{l}\text { Community } \\
\text { organization }\end{array}$ & \\
\hline 9 & $\begin{array}{l}\text { Evaluation the } \\
\text { volcano }\end{array}$ & & & $\mathrm{BPBD}$ & $\begin{array}{l}\text { TNI- } \\
\text { Polri- } \\
\text { SKPD }\end{array}$ & $\begin{array}{l}\text { Community } \\
\text { organization }\end{array}$ & \\
\hline
\end{tabular}

Source: Lestari et al., 2014.

Regional Work Unit), community organization, and Media. For more details of the researchers present, the table of activities and the role of the actor's contingency plan, see below:

\section{Results}

According to Government Regulation No. 21 the Year 2008 on the Implementation of Disaster Management, every single place has to own its contingency plan, especially the prone areas. Karo is one of the areas disaster-prone. This is why a contingency plan is indispensable in this area.

The contingency plan of Mount Sinabung eruption has not been well implemented. There is no contingency plan that is used as a guide in disaster management eruption Sinabung because no one knows that they have a contingency plan. The search results of the investigators found Sinabung eruption contingency plan made by Badan Nasional Penanggulangan Bencana (BNPB, National Disaster Management Agency) center in 2014. The documents were kept in central BNPB, and the documents were not found in Karo District. Reasons for not finding the document involve the turn of leadership in the Regional Disaster Management Agency (BPBD). This research found a new format of communication models of disaster risk reduction, which was based on the community through contingency plan.

According to interviews in 2014 until 2018 with Chief Executive of BPBD Karo and Head of Preparedness Division, the Karo District Government, notably BPBD, has no contingency plan document. The interviewees state the same answer: to overcome the Sinabung disaster, they use the Action Plan document, or what is known as the Operation Plan. There is no principle difference between 
the Contingency Plan and the Plan of Operation that was made by BPBD, except for the preparation time only. Contingency plans are prepared ahead of and before a disaster, so the plan is based on assumptions and scenarios. While the Operation Plan is prepared at the time the disaster happened so that the plan is arranged by real circumstances, the operating plan is prepared by adjusting the type of activities and resources contained in the contingency plan, based on the real needs of the type of disaster that has occurred.

Based on the information, the researchers tried to find information to BNPB Center; the result was the Contingency Plan eruption of Mount Sinabung in 2014. Researchers confirm to BPBD Karo District through the chief executor, secretary, and head of preparedness about the existence of documents that make up Contingency Plans. The result is they do not understand the document because of the change of officials in the Regional Disaster Management Agency (BPBD). Considering there is a document of contingency plan from the Regional Disaster Management Agency (BPBD), this research program is in the form of updating contingency plan data that has been made by BNPB 2014. The updating of this data is possible so that the planning can be close to the facts in the field. Data updating is based on a guidebook for the preparation of contingency plans issued by the central BNPB, including activities in the framework of this follow-up plan, which are listed in the table containing the stages and actors or sectors as well as the timing of the activities. The contingency plans update model found in this study.

BNPB always makes the contingency plan, but, the contingency plan is developed without involving community or people. Based on the results of the interview in 2015 - 2017 to Martin Sitepu (chief executive BPBD 2017), Matius Sembiring (chief executive BPBD 2016), Subur Tarigan Tambun (chief executive BPBD 2015). Then, Hasym Purba (head section of preparedness 2017), Rani Barus (staff preparedness BPBD), Johnson Tarigan (secretary BPBD 2014 - 2016), contingency plan made by BNPB were not know by BPBD and regional governments. These researchers wanted to renew the plan contingency which had previously been made by BNP with a topdown system.

In this study, researchers who conducted the renewal of the planned contingency had previously been arranged by BNPB. The renewal is the community involvement in making the contingency plan. The following are models of communication disaster in disaster risk reduction community-based through a contingency.

The process of updating the Contingency Plan documents involves communities both at the government and community levels around Sinabung as mentioned in the research method. The process first includes inventory and maintenance of availability and readiness of resources, facilities, and infrastructure in each area done periodically. Second, periodic meetings for review to update data and assumptions of disaster impact or projected resource needs. Third, establish fixed procedures that can support the implementation/activation of contingency plans that have been prepared. Fourth, conduct periodic monitoring of threats and early warning and dissemination.

In updating the contingency plan document, the researcher conducts an inventory of data related to the number of refugees, the necessary infrastructure, the resources to be prepared, the responsible personnel, the prepared shelters, and various matters related to the eruption disaster of Sinabung. The data has been written in the document Sinabung contingency plan results of data updating.

One thing to note is that in principle, the preparation of contingency plans, other than those jointly prepared by all stakeholders, also included preparing scenarios and conducting a needs analysis. There was an increase of 
Figure 2.

\section{Communication Models of Disaster Risk Reduction Based on Community through Contingency Plan}

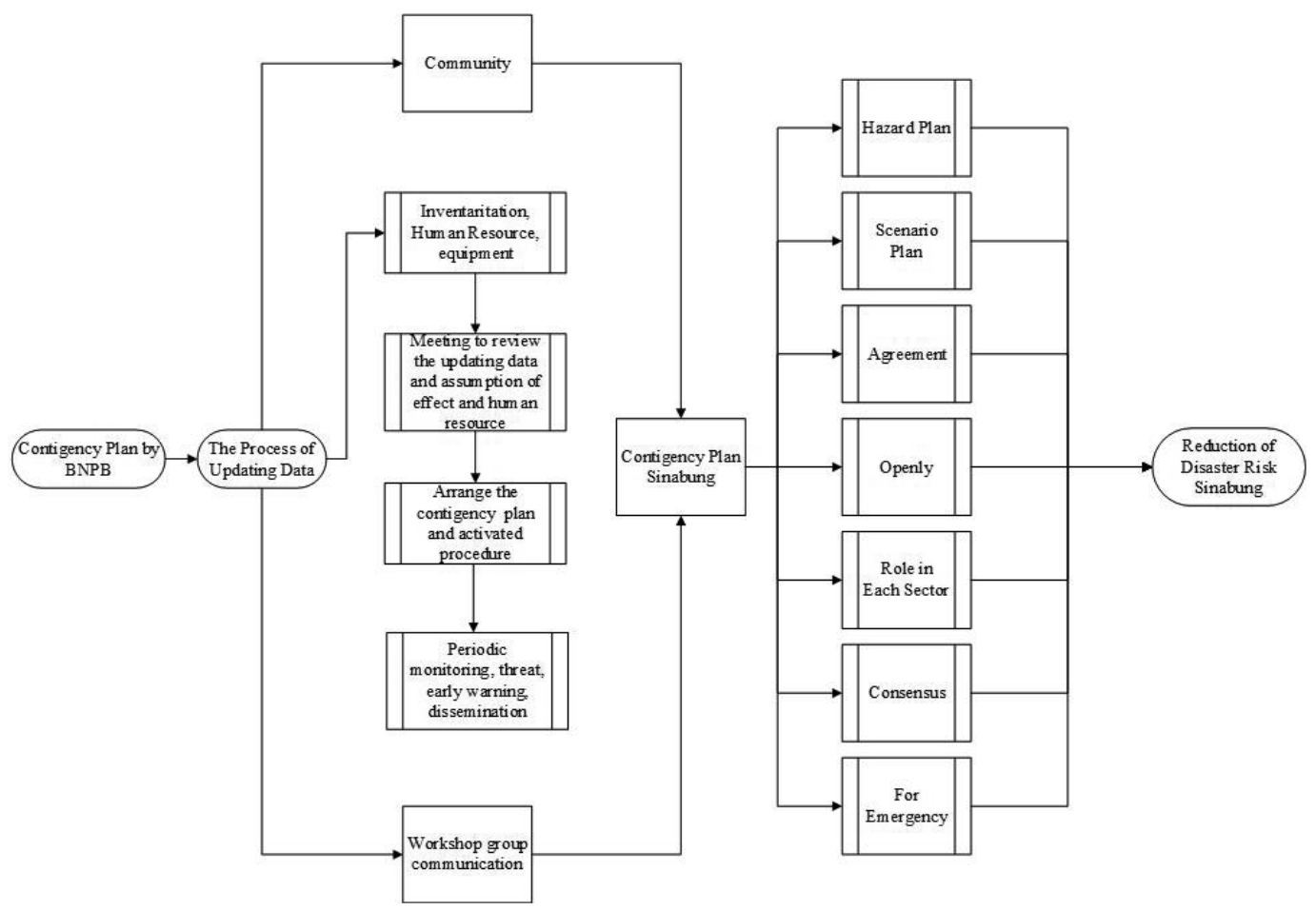

Source: Researcher's Data 2017

interaction in the network by arranging such mechanisms and enhancements of actors' capacity (Sagala et al., 2014). Once the needs are calculated in detail, it is determined who the perpetrators are, and do not forget to make an assessment of resources owned by the perpetrator or stakeholders. From the needs and availability of these resources will be known gaps that will be met from various sources that prioritize local and surrounding resources.

Contingency plans are prepared jointly by various parties/elements/components of society. This is intended as an effort of preparedness by all parties because disaster management is a standard affair among government, business entities, and communities where the government is the primary responsibility. Each of the parties or actors may play an active role according to their competence, expertise, ability, and authority and contribute or use existing resources within the scope of their powers or authorities. Preparation of a contingency plan is preceded by a coordinated meeting, followed by a meeting or workshop. Stages of preparation of contingency plans start preparation until implementation can be seen in Figure 3.

Hazard assessment is done through the identification of threat types and weighing threats.

a. Identify the types of disaster threats using records data/history of disaster events.

b. Weighing/scoring of threats/hazards of several types of threats in a district/city and assessing each one.

The development of impact scenarios explains the impact assumptions on life aspects of a disaster event, especially on the community/ 
Figure 3.

Compilation of Contingency Plans

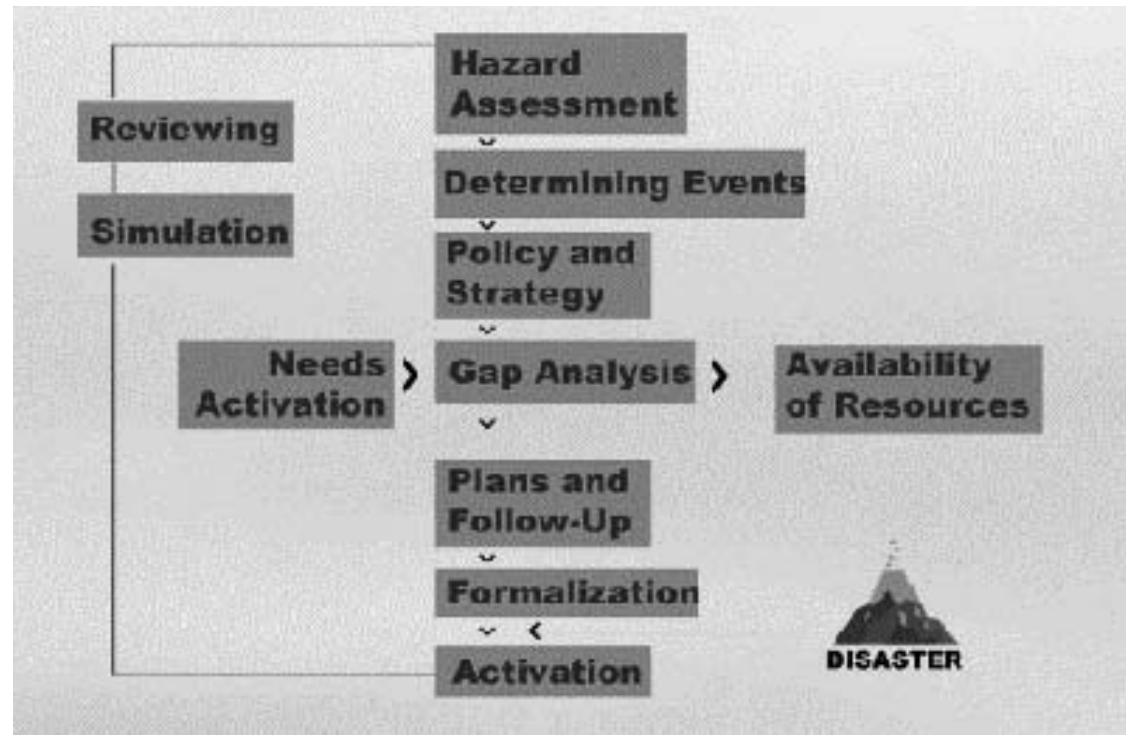

Source: Tatas, I Putu Artama Wiguna, Machus, Tridani Widyastuti, 2015

population, taking into consideration the vulnerability and local capacity of the affected communities, including community awareness of risks, preparedness, and availability of resources in disaster management. As a result of the Sinabung eruption disaster, Pusat Vulkanologi dan Mitigasi Bencana Geologi (PVMBG, Center for Volcanology and Geological Hazard Mitigation) recommended that the population within a radius of $10 \mathrm{Km}$ from the crater be evacuated. The community evacuated using transportation owned by citizens and government that were prepared since the alert status. The evacuation was done from the gathering place in the village which then used the prepared truck to the evacuated shelters. According to the data, there are as many as 40 evacuation areas.

1. The assumption of the number who died, were wounded, disappeared, evacuated, and moved is as follows:

a. The number of villages affected by the disaster within a radius of $10 \mathrm{~km}$ in 53 villages, with a total population of 57,879 inhabitants. b. The assumption of population impact involved 12 dead, 16 lost, moved as many as 2509 were moved, 55,341 displaced people, 55 with severe injuries, 165 with moderate wounds, 553 with minor injuries, and 54,275 not affected.

2. The impact of the eruption of Mount Sinabung in the form of ash rain resulted in flight disruption at Kuala Namu Airport in Medan City.

3. The road from Medan to Berastagi, Kabanjahe and Aceh Province is very busy road lane and will be hampered by the closing of the road for several hours to evacuate people from the affected villages to evacuation sites, as well as distribution activities of emergency assistance and disaster relief.

4. With experience, the length of eruption of Mount Sinabung and displacement is more than two months. It will disturb the learning and teaching process in affected schools.

5. Impacts on the livestock sector include cattle, buffalo, goats, horses and pigs. 


\section{The Determination of Policy and Strategy}

The emergency handling policy is intended to guide the relevant sectors to act/ implement emergency response activities. The policy is binding because in emergency management, there are treaties that must be obeyed by all parties. Examples of policies are (1) determining the time of emergency response to be carried out (e.g., for 14 days), (2) free care/ treatment services for disaster victims.

Emergency management strategies are implemented by each sector according to the nature of sector tasks. This strategy is aimed at the effectiveness of policy implementation. For example, from the policy of "free care/ treatment service for the victim" can be formulated strategy "appointing government hospital/private that serve as the referral hospital."

\section{Sectoral Planning}

The first step in sectoral planning is identification activities. All activities for handling urgent things have to be identified so the problem is tackled and completed. There are no activities that overlap and no vital activities who were left behind. Those responsible for implementation plan drafting contingency joined in sector (for example: management and coordination, evacuation, food and non-food, health, transportation, infrastructure). About the sector, the number and the nomenclature is determined by actors contingency plan drafting. There was no stipulation defined in determining the number of and naming to sectors.

\section{- Sector situation}

The situation was an image of the worst condition during the incident intended to anticipate the level of difficulty in handling the emergency.

- Sector target

Intended as goals to achieve in handling of emergency so those of the community or the victims can be treated to the fullest.

\section{- Sector activity}

Is that the was conducted during emergency to ensure that the the joined sektor could be actively sector. Sector activities triggered by situation sector during the incident disaster.

\section{- Sector's actor identification}

The emergency management sectors were derived from a number of elements, such as good government and non-government, including members of the community broad.

\section{- Implementation time activities}

The implementation time activity by sector is before the natural disaster, for a moment after the disasters and after as needed.

The local government of Karo Regency has set a 14-days Emergency Response Status based on warnings issued by the Center for Volcanology and Geological Hazard Mitigation (PVMBG). The length of the emergency response period will be evaluated based on escalation of a disaster event or a recommendation from Center for Volcanology and Geological Hazard Mitigation (PVMBG). Where necessary, the emergency response period may be extended. In response to the establishment of emergency response status, the Bupati shall appoint an emergency response commander. The emergency commander will be given a decision letter and authority to perform emergency handling according to regulation. The next post will be established at the Office District Kabanjahe with the organizational structure as follows.

Volcanology and Geological Hazard Mitigation says the population within a radius of $10 \mathrm{~km}$ from the crater must evacuate. The community evacuates using transportation owned by citizens and government that have been prepared for the status of "SIAGA."

To coordinate and control the implementation of emergency response, field committees were established in all the evacuation sites, being one with health 
post, public kitchen, emergency education, field logistic warehouse, and security. The evacuation center was spread over 40 refugee districts in Berastagi sub-district, Kabanjahe, Munte, and Tigabinanga, in detail on the table. Support from the central level of the National Disaster Mitigation Agency (BNPB), relevant Ministries/Agencies, Provincial-level support, and other districts/municipalities, support assisting organizations of emergency response organizations in field implementation.

Disaster Risk Reduction Policy has a goal to improve disaster preparedness and to keep development activities from increasing the vulnerability of communities to disaster threats. Contingency planning (as well as other types of plans in disaster management) can be structured at the community level. This is an effort to accelerate capacity building at the community level to manage and mitigate disaster risks. Moreover, the territory of NKRI is so vast that it is impossible for the government to handle itself. In general, government plays essential political, economic, cultural, and social roles in risk governance systems that include resource assurance, technical support, and disaster risk management (Shi, 2012). Therefore, community empowerment is needed by building the capacity of people in disasterprone areas that are at high risk, for them to be resilient to disaster. Communities are the first to deal with disaster risks, so they must be able to cope.

This model is the process of updating the data of contingency plan to reduce the impact of the eruption of Mount Sinabung especially during the emergency response in the form of Contingency Plan document (Triutomo et al., 2011). The contingency plan becomes a document of Karo District Government that is endorsed or signed by the authorized official. The Regent of Karo has become an official document (regional document) and is ready to be implemented into an Emergency

Figure 4.

Organization Structure of Emergency Respond Comand



Source: Researcher's Data 2017 
Response Operation Plan (through damage information and the need for results from fast study activities) when disaster strikes. The contingency plan will also be submitted to the legislature for political commitment, support and budget allocation. At this stage of the study, Contingency Plan products have not yet obtained formal approval as the pilot stage or new post-rehearsal will be conducted in second-year research (2018).

All contingency plans are updated with the team with all Head of Region Working Units (SKPD) of Karo District along with mass organizations and affected communities, according to the latest data. The temporary draft has been requested by The Regional Disaster Management Agency (BPBD). Karo through Rani Barus's brother in June 2017. Rani Barus is a staff preparedness of The Regional Disaster Management Agency (BPBD). Hopefully, this draft can be completed at a later stage and refined to be one of the Sinabung eruption risk reduction policies in Karo Regency of North Sumatera.
To make the updating happen, the researcher held a workshop to submit a person from every sector. In that workshop, all the participants should be more proactive in completing data of Contingency Plan Sinabung which will become the reference in case of significant disaster related to the eruption of Sinabung. The researchers make a chart of activity and role of actors implementing if disaster happens. The chart is below.

Research findings will be reform documents of the contingency plan for the eruption of Sinabung to give a reference in planning to face disasters in disaster risk reduction. The contribution of research findings this provides eases the tools on the parties or agencies, especially North Karo regency, to reduce the impact of disaster risk in traffic agents. Cross-sectors and cross functions are integrated based on assumptions and deals produced. Having a document contingency plan means regional governments have implemented the message of the act of number

Figure 5.

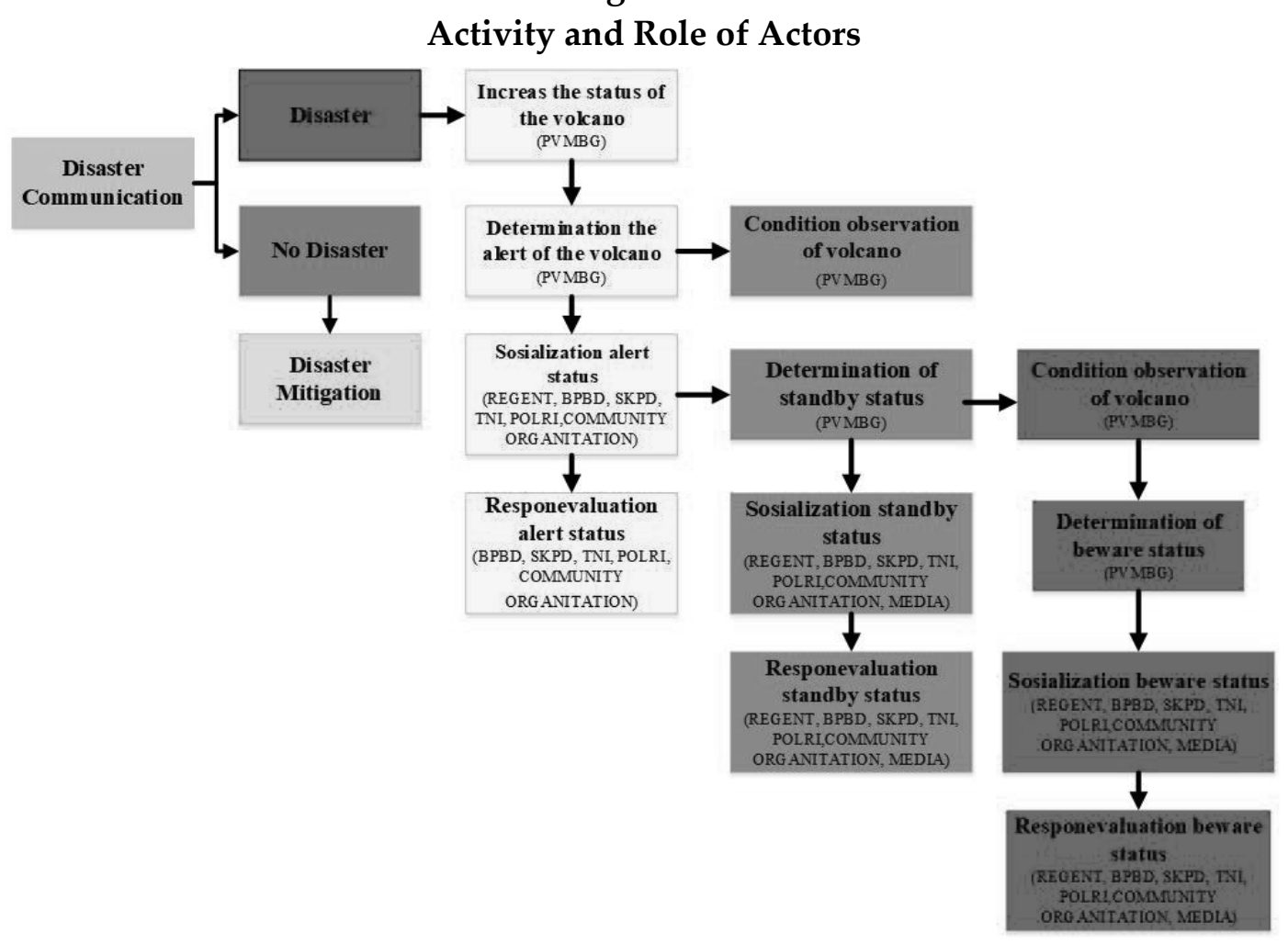

Source: Researcher Data 2017 
twenty-four 2007 and government regulation No. 21/2008 on disaster reduction.

\section{Discussion}

Each local government, especially in disaster-prone volcano areas, have document contingency plans, such as Daerah Istimewa Yogyakarta, Klaten and Magelang Central Java have created a planned contingency with the disaster center of Universitas Pembangunan Nasional Veteran Yogyakarta. Due to the unknown previous contingency plan, community thinks they need that contingency plan. It makes the researcher, $\mathrm{BNPB}$, and $\mathrm{BPBD}$ to be the facilitator in making the new contingency plan which is community-based. There was the communication model to make an updating data for the new based-community contingency plan. Chart five below explains how the communication model is to create a new contingency plan.

Based on models of communication, one can conclude that any element involved having the role of each. Pusat Vulkanologi dan Mitigasi Bencana Geologi (PVMBG, Center for Volcanology and Geological Hazard Mitigation) have an important role in providing information on the status of Sinabung Volcano. Information on related mountain status was collected of postal officials observer Sinabung volcano. The observer then will continue information to the head of the region (regent), BNPB, BPBD, and media. After information delivered to the regent, $\mathrm{BNPB}, \mathrm{BPBD}$ the media, then broadcast to the community.

BNPB has an important role as the representative of the central government that had the task of coordinating various matters disaster management between the government of the central and local government. BPBD having the role of the chief executive in the event of the disaster should have the task of coordinating all the elements that exist. A media that is involved in a contingency plan is a whole media from all the major platforms: radio, the printed media, television based on community and mainstream media. Not only that, media centers from the agency had yet to receive anything from the Communication and Information Department, which also has a role in delivering trusted information accurately to the community.

Satuan Kerja Perangkat Daerah (SKPD, Regional Work Unit) comprising all the relevant offices (Education Department, Health Department, social Department, the Environment Department, Forestry Department, energy and mineral resources Department, of public works Department, etc) coordinated by the Regent of great political pressure to implement the role of in accordance with the divine stewardship, according to their role. Komando Distrik Militer (Kodim, Military Command District) has many roles coordinate to make a statement on to mobilize the assistance in the form of evacuation and the distribution of assistance. The Polisi Resort (Polres, Police Resort) have a role to coordinate security and traffic at the time of the evacuation.

Civil society organizations consisting of Tagana (disaster preparedness community), the church community, and the mosque community have an important role assisting all the evacuation processes until the provision of the evacuation center. The community played a role in actively participating in the whole process of evacuation by instructions from local authorities. They are expected to create conditions for the community.

Disaster management efforts communication can be done among others with the management of disaster risk based the community as calamity mitigation practices that instituted the reign of knowledge and the concept of a more systematic approach. Community-Based Disaster Risk Management is a reflection of the belief that the community has the right entirely to determines the types and the manner of disaster management in the context of them. The ownership of the fundamental rights of individuals on the person and the 
Figure 6

Communication Model to Create a New Community-based Contingency Plan

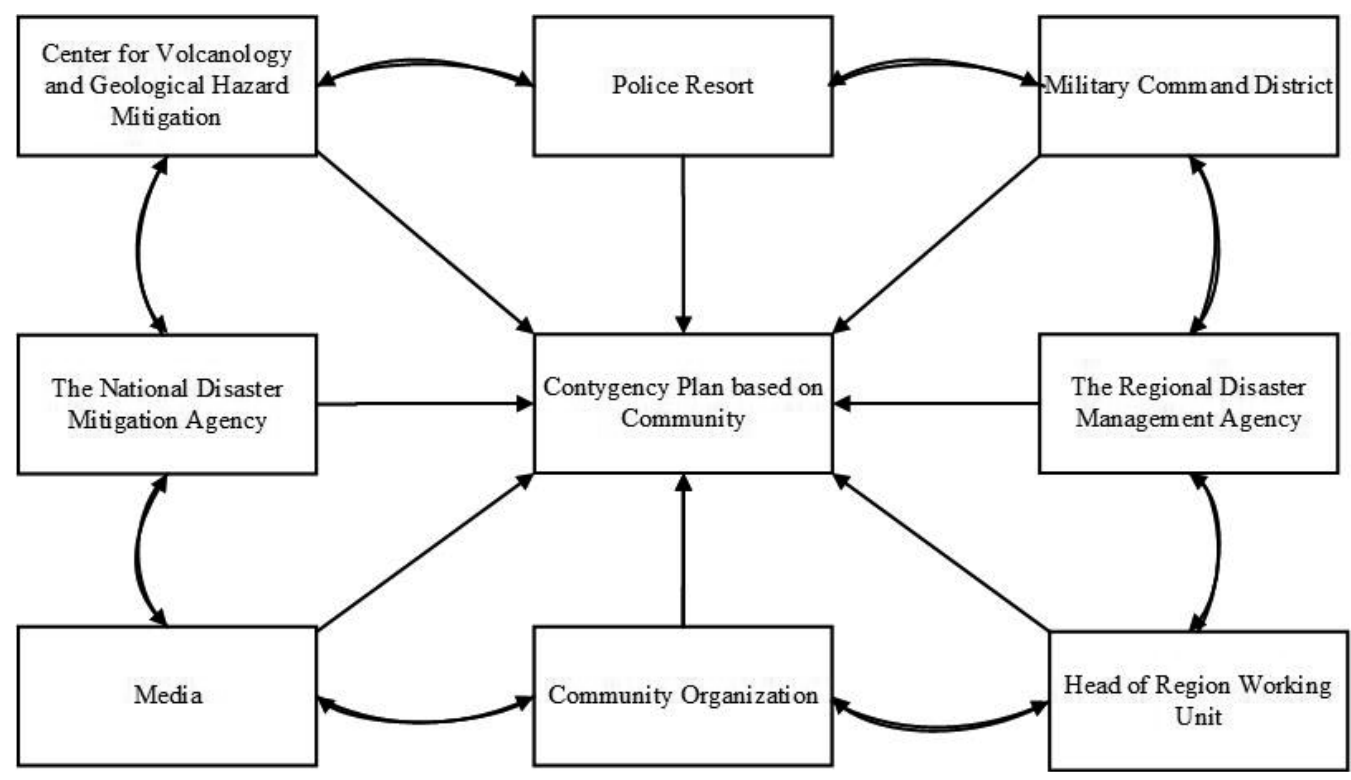

Source: Researchers Data, 2017

community (the community) that sticks with the right to exercising the right it in the form of a chance to determine the direction of life alone (self-determination). The importance of community action - for disaster risk reduction, for post-disaster rebuilding and climate change adaptation (Satterthwaite, 2011).

Community-Based Disaster Risk Management gives you the answers includes some principle as efficiency available because low transaction cost is done because there are local intake maximum and minimum external intake. Community-Based Disaster Risk Management because of the implementation of the matter with sustainability issue as Community-Based Disaster Risk Management also ensures the effectiveness of, the legitimacy of (participation), and equality (equity) could not be fulfilled. All the community can give that owned voluntarily. Management will arrange by the communities themselves in accordance with local knowledge.

After models of communication community based disaster were described, the result of the formation of that model was a kontinjensi eruption plan. Preparation of contingency plans may be undertaken through prior training activities, or through other forums such as coordination meetings, followed by meetings or workshops, or other forms of activities. The formulation of a contingency plan must be done through preparation and implementation.

The preparation of activities include the provision of a map districts provincial, data "districts in figures," data about the supply of resources of the respective sectors/the office's organization/and information from various sources that can be accounted for technically.

In the implementation stage, their activities of contingency plan drafting, which began in risk assessment, preceded by hazard assessments and determination of the danger to determine one type of a threat or disaster expected to occur (which became the priority).

The implementation of disaster risk management based on community should help reduce the risk of disaster in Indonesia. 
The community-based approach also corrected the defects of the top-down approach in development planning and disaster management, which failed to address local needs, ignored the potential of indigenous resources and capacities, and may have even increased people's vulnerabilities (Victoria, 2002). The environmental damage and behavior of the community improved. This can be seen from the events that feed on dozens of deaths and thousands of refugees fleeing. The implementation of a model Community-Based Disaster Risk Management to reduce disaster around Mount Sinabung is of importance to realize the communities that actually are tough. The government is responsible for land-related disaster risk reduction, but the community is more responsible for those who are vulnerable to a dangerous eruption phase of the volcano.

\section{Conclusion}

Once a contingency plan has been drawn up on the basis of a community, the community becomes ready to take part in disaster risk reduction. Disaster Risk Reduction Policy has a goal to improve disaster preparedness and to keep development activities from increasing the vulnerability of the communities to disaster threats. Contingency planning (as well as other types of plans in disaster management) can be structured at the community level. If it formed by the government and the community; it makes both sides understand each other if disaster happens. This is an effort to accelerate capacity building at the community level to manage and mitigate disaster risks. Moreover, the territory of NKRI is so wide that it is impossible for the government to handle itself. Therefore, community empowerment is needed by building the capacity of people in disasterprone areas that are at high risk in order for them to be resilient to disaster. Communities are the first to deal with disaster risks, so they must be able to cope.

\section{Acknowledgement}

We would like to thank all parties involved in the preparation of the document of contingency plan for the eruption of Mount Sinabung, especially DRPM Kemristekdikti, which funded this research through the 2017 Higher Education Research Grant (PUPT). Also research Institute and Community Service (LPPM) of National Development University Veterans of Yogyakarta, BupatiKaro, Regional Secretary, Assistant Regent, Regional Disaster Management Agency (BPBD) of Karo Regency along with a team of Local Government Work Units (SKPD), NGOs, Volcanology and Geological Disaster Mitigation Center (PVMBG), Sinabung Observation Post Officer, and participants of the workshop of Contextual Renewal of Sinabung 2017 Plan.

\section{References}

Afianti, Y. (2008). Focus group discussion sebagai metode pengumpulan data penelitian kualitatif. Keperawatan Indonesia, 12(1), 58-62.

Asteria, D. (2016). Optimalisasi komunikasi bencana di media massa sebagai pendukung manajemen bencana. Jurnal Komunikasi Ikatan Sarjana Komunikasi Indonesia, 1(1), 1-11.

Iguchi, M., Ishihara, K., Surono, \& Hendrasto, M. (2011). Learn from 2010 Eruptions at Merapi and Sinabung Volcanoes in Indonesia (54 B ed., pp. 185-194). Kyoto: Disaster Prevention Research Institute, Kyoto University.

Lestari, P., Kusumayudha, S., Paripurno, E., \& Jayadianti, H. (2016). Environmental communication model for disaster mitigation of Mount Sinabung Eruption Karo Regency of North Sumatera. iNFORMATION An International Interdisciplinary Journal, 19(9B), 4265-4269. Retrieved from http://eprints. upnyk.ac.id/14491/1/Information $\% 20$ Journal.pdf 
Lestari, P., Sembiring, I. D., Prabowo, A., Wibawa, A., \& Hendariningrum, R. (2013). Manajemen komunikasi bencana Merapi 2010 pada saat tanggap darurat. Jurnal Ilmu Komunikasi, 10(2), 173-197. doi: 10.24002/ jik.v10i2.350

Nasution, M. S. (2005). Penanggulangan bencana berbasis komunitas: studi kasus kesiapsiagaan bencana berbasis komunitas daerah rawan bencana alam tanah longsor di Desa Kidangpananjung Kecamatan Cililin, Kabupaten Bandung, Jawa Barat. (Unpublished master's thesis). doi: doi. org/10.1017/CBO9781107415324.004

Presiden Republik Indonesia. (2007). Undangundang Republik Indonesia Nomor 24 Tahun 2007 tentang Penanggulangan Bencana. Jakarta.

Presiden Republik Indonesia. (2008). PP RI No 21 Tahun 2008. Peraturan Pemerintah. Jakarta.

Putra, A. (2017). Analisis bahaya Gunung Sinabung. Kementerian Energi dan Sumber Daya Mineral, Badan Geologi, Pusat Volkanologi dan Mitigasi Bencana Geologi \& UPN Veteran Yogyakarta. Retrieved from http:// eprints.upnyk.ac.id/13911/1/ANALISIS BAHAYA GUNUNG SINABUNG APRIL 2017.pdf

Sagala, S. A., Situngkir, F., \& Wimbardana, R. (2013). Interaksi Aktor dalam rekonstruksi rumah pasca bencana gempa bumi. MIMBAR, Jurnal Sosial dan Pembangunan, 29(2), 217. doi: 10.29313/mimbar.v29i2.397. Satterthwaite, D. (2011). Editorial: Why is community action needed for disaster risk reduction and climate change adaptation? Environment and Urbanization, 23(2), 339-349. https://doi.org/10.1177/0956247811420009
Shi, P. (2012). On the role of government in integrated disaster risk governance-Based on practices in China. International Journal of Disaster Risk Science, 3(3), 139-146. doi: https://doi.org/10.1007/s13753-012-0014-2

Suri, N. K., \& Utara, U. S. (2015). Analisis Kinerja Badan Penanggulangan Bencana Daerah Kabupaten Karo dalam upaya penanggulangan bencana erupsi Gunung Sinabung di Kabupaten Karo. Perspektif, 8(1), 456-477.

Sutawidjaja, I. S. Prambada, O., \& Siregar, D. A. (2013). The August 2010 Phreatic Eruption of Mount Sinabung, North Sumatra Letusan Freatik Gunungapi Sinabung Agustus 2010, Sumatra Utara. Indonesian Journal on Geoscience, 8(1), 55-61. doi: 10.17014/ijog. v8i1.155

Tatas, T., Wiguna I. P., Machus, M., Widyastuti, T. D., \& Rohman, M. A. (2015). Rencana kontinjensi untuk tanah longsor. Jurnal Aplikasi Teknik Sipil, 13(2), 27-40.

Triutomo, S., Widjaja, B. W., Siswanto, B. P., \& Yohannes, K. (2011). Panduan perencanaan kontinjensi menghadapi bencana. Jakarta: Badan Nasional Penanggulangan Bencana (BPBD).

Victoria, L. P. (2002). Community based approaches to disaster mitigation. Regional workshop on best practices in disaster mitigation, 270-314. Retrieved from http://unpan1. un.org/intradoc/groups/public/documents/ APCITY/UNPAN009661.pdf

Wu, T., Takara, K., \& Yamashiki, Y. (2012). The vulnerability variation from government roles in disaster risk reduction plans for sediment disasters in Taiwan. Hydrological Processes, 26(16), 2421-2430. https://doi. org/10.1002/hyp.9346 